\title{
HISTORICAL RETROSPECTIVE: JEWISH WOMEN OF BELARUS IN THE DEVELOPMENT OF DENTAL TOURISM (SECOND HALF OF THE 19 - EARLY 20TH CENT.) \\ Y. YARMAK
}

Yanka Kupala State University of Grodno

Republic of Belarus

\begin{abstract}
The article based on archival documents will consider such a direction in the tourism industry as medical tourism. Dentists were pioneers in this area in Belarus, but the history of this industry is much older than one might think. In the late 19th and early 20th cent. Jewish Pale of Settlement passed through the territory of Belarus. Belarusian provinces, which constituted a significant part of the Jewish population in that period entered a period of dramatic changes. The modernization process resulted in the appearance of women in public spheres. Since the second half of the 19th cent., after the development of the regulatory framework, it becomes possible to obtain the specialty of a dentist. Archival documents from the National Historical Archive of Belarus (NHAB) in Grodno and Minsk show that the dental industry was very attractive to Jewish women. Druskeniki was a special place for the Jewish population. Women Jewish dental offices were in great demand not only among the Jewish population, but also among Christians. This activity gave women the opportunity to have their own income, and, therefore, freed them from patriarchal dependence, destroying gender stereotypes imposed by society. The process of emancipation of the female Jewish population began. The end result of these processes was the formation at the turn of the 19 th - early 20 th cent. a new type of independent woman.
\end{abstract}

Key words: Jewish women; Jewish Pale of Settlement; tourism; dentist; Druskeniki; gender stereotypes.

For citation: Yarmak, Y. (2020) Historical retrospective: jewish women of Belarus in the development of dental tourism (second half of the $19^{\text {th }}$ - early 20th cent.). In: Actual problems of international relations and global development: collection of scientific papers. Minsk, Vol. 8, p. 147-159. https://doi.org/10.33581/2311-9470-20208-147-159

Introduction. One of the features in the life of Belarusian cities and towns in the second half of the 19th - early 20th cent. was an active socioeconomic role of the Jewish faith women. This activity was also expressed 
in the fact that Jewish women actively sought to get an education. Education made it possible to have a constant source of income. For Jewish population, the special importance of education was the possibility of free movement around the empire. If there is a lot of information about the men participation in the development of various society spheres, then the history of women participation is still outside the scope of historical research.

Modern trends in the development of gender studies require the inclusion of the history of women in the canvas of general historical research, since without this segment, historical knowledge will not be complete. The growing influence of women in the modern world, the availability and comfort of tourist travel, including medical (dental) tourism, makes the topic of studying the contribution of Jewish women to the development of dental tourism relevant.

Literature review. Documents from the National Historical Archive of Belarus (NHAB) in Grodno and Minsk were used as sources. Extensive factual material is presented in the fund 9 of the «Medical Department of the Grodno Provincial Board» in the NHAB in Grodno. Documents containing information about the opening of dental offices, passing exams for the title of dentists, private cards of dentists are of particular value. NHAB in Minsk contains fund 299 «Minsk Provincial Board» where information of dentist schools is provided.

The laws regulating the activities of Jews as doctors are presented in the collection of M. I. Mysh [1].

The participation of the Jewish faith women in the development of dentistry as one of the areas in medical tourism has not been previously studied in Byelorussian historiography. N. Shumin investigated the history of the creation and functioning of the first specialized educational institution for the training of dentists in Belarus - the Dental School of L. Shapiro and A. Demikhovsky in Minsk, not to the fact that most of the students were women of Jewish origin [2].Article devoted to the Jewish medicine was written by O. Sobolevskaya [3].Turning to foreign historiography, mention should be made of the monograph edited by N. Berger «Jews and Medicine: Religion, Culture, Science» [4]. A separate chapter is devoted to Jewish women doctors. But author pay attention to the hole medicine, and didn't focused on dentistry as a factor influences on the development of tourism.

Research methods. In the process of studying women's participation in the development of dental tourism, the methods used allowed us to con- 
sider the main aspects of this action. The basis was the principle of historicism. Due to the topic gender approach was used. The study used retrospective and descriptive methods.

The object of the research is the system of tourist relations on the territory of the Belarusian provinces in the second half of the 19th - early 20th cent. The subject of study is the participation of Jewish women in Belarus in the development of dental tourism (second half of the 19th early 20th cent.).

Results of the research. Difficult socio-economic conditions within the boundaries of Jewish settlement: a ban on living in rural areas, overcrowding of Jews in small towns and villages, great competition in the labor market, and as a result, the general poverty of the bulk of the Jewish population contributed to the fact that, Jews sought to receive medical education and with the help of the profession received, leave the Pale of Settlement. Medical specialties were highly respected among Jews and served as a source of income. Here it should be clarified that only Jews worked in the dental field, women of other nationalities were not represented. Jewish women were under the yoke of double discrimination, and because of their gender (this problem was typical to the late 19th - early 20th cent.), and as Jewish women because of their nationality restricted by law. These reasons influenced the worldview of Jewish women and contributed to their greater emancipation.

Until the last quarter of the 19th cent. dental care for the population was provided by doctors, barbers and paramedics. Dentists were extremely small in number and mainly served to the wealthy classes of society. In addition, the services they provided did not always give the desired result. In the 90's of the 19th century, more than 40 dentists were registered on the territory of Belarus (Vitebsk, Grodno, Minsk, Mogilev provinces) [2]. However, the quality of the services provided by them, as before, remained at a low level.

Criticizing the quality of the provision of medical services, we become victims of the influence of modernization, not considering that the level of development of medicine at that time was low and forgetting that the main value of any assistance is humanity. Despite the need for medical workers and the prestige of the type of activity itself, it was difficult to obtain this profession. In the second half of the 19th - early 20cent, the discriminatory policies of the Russian government led to the introduction of a percentage rate for Jewish students. The acquisition of a medical specialty 
placed Jews on the border of two cultures. Medical education gave a pass to the world of European culture, and for a woman (midwife, dentist, paramedic) it became means of emancipation.

Until $1891 \mathrm{y}$., there were no special training programs for dental technicians; they were classified as a jewelry workshop. After the adoption of the relevant normative documentation, which officially consolidated the division of specialists in the field of dentistry into dentists and teeth doctor, the development of rules governing their further activities (Law «On the transformation of teaching dental art» (May 7, $1891 \mathrm{y}$.), «Normal charter of dental schools» (May 28, $1891 \mathrm{y}$. and May 24, $1892 \mathrm{y}$.)) there was an opportunity to open dental schools. The title «dentist» was given to those who were trained by practicing dentistry in private offices, and to become a doctor «dentist» it was necessary to graduate from a dental school.

In 1893 y., the Medical Department became concerned with the problem of inaccurate advertisements that were published in newspapers by people providing dental services. «From the available information it appears that some of the dentists published their publications about themselves

a) added to the words of the dentist the words «inserts teeth, fills and performs various operations»;

b) denoted prices for artificial teeth with the addition of the words «with a guarantee»;

c) added instructions for obtaining the title of a member of the French National Academy, for the ability to insert teeth without pulling out the roots, for the invented thymol dental remedies that seem to kill a nerve;

d) added drawings to publications: medals, orders, operating chairs and other devices, and especially images of a face with and without teeth».

Having considered this case, the Medical Council found that the aforementioned society, as well as most of the dentists, call themselves doctors of dentistry and even had signs. Meanwhile, they do not have the right to this, in view of the printed No. 59 Collection of Laws. On June 11, $1891 \mathrm{y}$. of the Supreme Command for the transformation of the teaching of dental art:

1) that special practical scientific medical titles acquired by testing by persons studying the dental art a) dentist b) dentist doctors;

2) the title of dentist is acquired on the basis of Art. 478 Medical Regulations; 
3) for the preparation of persons wishing to obtain the title of dentist, dental schools are established, in which the course of study lasts two and a half years.

Since such schools were opened only in the autumn of 1891 y., at present there is only one title of dentist for persons engaged in the dental arts, and none of which have the right to be called a dentist doctor ${ }^{1}$.

Thus, dentists in print advertisements meant only their degrees, and that all praises (advertisements) of treatment methods were prohibited. Dentists cannot be called dentists doctors until they receive an established certificate for this title from universities or the Imperial Military Medical Academy, and they also have no right to place different images of medals and, in general, any kind of drawings, either on signs or in advertisements.

Before the normative base appeared, the title of dentist was obtained after training with a dentist.

In 1896 y., Haya Feinstein entered the Brest dental office as a student of Lurio ${ }^{2}$. She studied for three years, after which she received permission to pass the examination test. The examination board usually included the assistant to the Provincial Physician Inspector, a staff physician and a dentist who provided their own dental office and supplies that were used when the student passed the practical part of the exam. The examination fee in $1899 \mathrm{y}$. was 5 rubles. This money was used to cover the costs of materials provided by the dentist.

Why were the Jewish women so interested in medical education? The answer can be found in the Guide to Russian Jewish Laws, edited by M. I. Mysh [1], where there is a list of specialties that gives the right to universal residence according to the educational qualification. Jewish women were given the opportunity to move freely throughout the Russian Empire only as medical professionals. These included the following professions: pharmacy assistant, pharmacist, medical assistant, dentist, midwife. Paragraph 142 told: «Pharmacists are considered to be among the people who have the right to live everywhere.». Paragraph 143 gave the midwife the opportunity to live outside the Pale, even if her husband was not entitled to it. Paragraph 145 informed: «Dentists have the right of residence through-

\footnotetext{
${ }^{1}$ National Historic Archive of Belarus (NHAB) in Grodno. F. 9. Inv. 4. C. 22. 31.05.-11.06.1893 y. 17 sh.

${ }^{2}$ NHAB in Grodno. F. 9. Inv. 3. C. 295. 1896 y. 7 sh.
} 
out the empire. At the same time, it is prohibited to live outside the Pale of Settlement while studying at a dental school, you must submit a legal form or a passport confirming the right to reside in the area» [1, p. 187-189].

People with the above-named specialties were also allowed to engage in trade and industry. Those who were trained in medical specialties were given the right to live everywhere in the empire only for the duration of their studies. In St. Petersburg, district bailiffs were charged with ensuring that Jewish students were not engaged in trades. In addition, the pundit according to paragraph 155 , «communicates to his wife all the rights and advantages associated with his condition or rank, including the right to live everywhere» [1, p. 189]. This right was preserved during the life and after the death of the husband, during the divorce of the spouses. The only reason the wife could be deprived of this right was the commission of a crime. The children of these Jews (sons until the age of majority or until the end of the course in higher educational institutions, but not older than 25 , and daughters before marriage) could live on the territory of the entire Russian Empire both during the lifetime of their father and in the event of his death outside the Jewish Pale [1, p. 200]. Such laws created a stable motivation for getting an education.

Higher education for Jewish women from the Pale of Settlement was possible in the large cities of St. Petersburg, Warsaw, Vilno, Kiev. In small provincial towns, there was an opportunity to go to the training of a practicing dentist. Having analyzed the cards of female dentists, which have been preserved in large numbers in the funds of the NHAB in Grodno and Minsk, we can conclude that Jewish women from Grodno, Minsk, Mogilev and Vitebsk provinces went to study in Warsaw, St. Petersburg, Kiev, Kharkov, Yuryev, Kazan, where they could also get the title of pharmacist. However, this option for obtaining an education was available to few.

An analysis of archival files on admission to dentists for training in the Minsk, Grodno, Vitebsk, Mogilev provinces indicates that Jewish women predominated in this area. Acquiring a dentist degree for a Jewish woman meant the opportunity to gain financial independence. The women who had the means opened their own dental offices.

By the second half of the 19th cent., one of the components of a wellto-do lifestyle was taking care of one's own health, expressed in the prevention of diseases. Among wealthy Jews, it was popular to rent country houses to take a break from the hustle and bustle of city life. It is becoming fashionable to travel abroad for the purpose of health improvement. 
The statement from the Grodno governor on the number of people who received the right to travel abroad in $1881 \mathrm{y}$. was preserved. The statement indicated the last name, first name, patronymic, rank, and also had a column when and for how long a foreign passport was issued. So, in January $1881 \mathrm{y}$. the Grodno bourgeois woman Rokhlya Naden received a passport for 6 months, for the same period Sora Kaufman received a passport. In February 1881 y., out of 44 people who received passports, there were 4 Jewish women. In March, women did not receive passports ${ }^{3}$. The largest number of foreign passports was obtained in the summer season. This was due to the fact that travel in summer was easier than in winter. Wealthy Jewish ladies could afford to go on vacation and improve their health. As can be seen from the table, departures abroad by the female Jewish population were seasonal, increasing in the summer.

\begin{tabular}{|l|l|c|c|}
\hline № & 1881 y. & WOMEN & MEN \\
\hline 1 & FEBRUARY & 4 & 44 \\
\hline 2 & MARCH & - & 39 \\
\hline 3 & APRIL & 6 & 103 \\
\hline 4 & MAY & 16 & 162 \\
\hline 5 & JUNE & 19 & 196 \\
\hline 6 & JULY & 22 & 96 \\
\hline 7 & AUGUST & 7 & 72 \\
\hline 8 & SEPTEMBER & 6 & 64 \\
\hline 9 & OCTOBER & 6 & 30 \\
\hline 10 & NOVEMBER & 6 & 52 \\
\hline 11 & DECEMBER & 4 & \\
\hline
\end{tabular}

O. Sobolevskaya wrote about the fact that Jewish ladies traveled abroad to improve their health. Thus, at the beginning of the First World War, the philistine of the city of Grodno Adel Gurvich was in the resort of Franzensbad in East Bohemia. The balneoclimatic resort Ems was the goal of the trip of the townswoman Zelda-Basha Rudkovskaya and her daughter Malka. In Bavaria, in the summer of 1914 y., Rivka Vinograd and her daughter-in-law Masha rested. Grodno resident Iosel Reznikovsky with his wife Gnesia Zelikovna was in the clinic Berlin State University [3, p. 214]. Judging by the historical archives, Jews usually went to the Baltic and German resorts. The choice of these places was not accidental. Con-

\footnotetext{
${ }^{3}$ NHAB in Grodno. F. 1. Inv. 23. C. 771. 1881 y. 36 sh.
} 
venient geographical location in relation to the Belarusian provinces, a good knowledge of the Yiddish-German language and the presence of close cultural ties of Ashkenazi Jewry with German lands, contributed to the popularity of this direction.

One of the most popular Jewish resorts of the middle of the 19th early 20th cent. was Druskeniki, which was located 40 kilometers from the provincial town of Grodno. The Jews were attracted here by the comparative cheapness, respectable public, healing mineral waters, which helped to treat diseases of the digestive system.

Traveler and publicist P. Subbotin called Druskeniki a «Jewish resort» [5, p. 18]. In $1868 \mathrm{y}$., of all categories of the population who arrived in the town, the majority were nobles (270 people), Jews are in second place (226). Of those who used the mineral waters, 54\% (421 people) were Christians, 46\% (367 people) were Jews ${ }^{4}$.

In Druskeniki, you could take baths, drink water and enjoy the healing air of pine forests, walks along the Neman River. The town became a center of pilgrimage for hundreds of wealthy Jews of Grodno, Vilno, Kovno and other large cities, which was facilitated by its favorable location on the borderlands of the Grodno, Kovno and Suwalki provinces. By the beginning of the holiday season, in addition to local doctors who constantly practiced at the resort, medical workers from large cities of the Russian Empire arrived in the town. Doctors came from Minsk, St.Petersburg, Vilno, Bialystok. As O. Sobolevskaya pointed out, in 1885 y. out of 30 doctors, only 5 were representatives of the Jewish nationality. Some doctors of the Christian faith came as a whole family to not only relax, but also undergo healing procedures. Some Jewish doctors came to Druskeniki by the invitation from the mineral water hospitals, some were free practitioners $[3$, p. 222].

Jewish system of charitable societies made it possible to some extent to get involved in health improvement poor Jews. The well-known ladies of Grodno society - Rebecca Rosenthal, Teresa Hazan, Fanny Halpern collected funds to finance the rehabilitation of indigent Jews in Druskiniki. According to the Warsaw edition of journal «Israelita», thanks to the help of benefactors, more than 300 poor people rested in this resort in $1880 \mathrm{y}$. $[6$, p. 46]. The poor patients who needed mineral water, fresh air and bathing could also apply to the Grodno charitable organization «Linas Gas-

\footnotetext{
${ }^{4}$ NHAB in Grodno. F. 9. Inv. 1. C. 123. 1868 y. 22 sh.
} 
edek». The charter provided payments for a person to stay alive in some cases, in particular, when a person's life depended on it (for example, the outbreak of tuberculosis) $)^{5}$.

At the Druskeniki resort, patients of both Jews and Christians were treated. The patients of the Jewish hospital were visited free of charge by a Christian doctor named Piletsky. Free aid to poor sick Jews in Druskiniki was offered by doctors who came to rest by the water. Among them were the doctors from Warsaw: the surgeon Ram and the gynecologist Venventohovski, the Vilnius midwife Bilg [7, p. 216].

At the expense of Jewish benefactors from Russia, a hospital was built, which received indigent holiday-makers who needed treatment. Rabbi Treger was the trustee of the asylum. In search of funds to create a hospital, Treger traveled around the nearby towns. Petersburg became the final destination during the collection of donations for the organization of the hospital. It is known from archival sources that in $1880 \mathrm{y}$. more than 400 poor people came to Druskeniki, about 4000 rubles were spent on their treatment ${ }^{6}$.

The town of Druskeniki during the second half of the 19th - early 20th cent. became a special place for the Jewish population. Not only healing mineral water and pine air attracted wealthy Jews there. The opportunity to receive dental care in numerous dental offices opened by fellow believers also contributed to the development of Druskeniki as a center for medical tourism.

This statement is confirmed by archival sources from the NHAB in Grodno. In fund 9 «Medical Department of the Grodno Provincial Board» 29 cases have been preserved concerning the opening of dental offices in the Grodno province at the turn of the 19th - 20th cent. Of these, 12 cases are petitions to open offices in the town of Druskeniki. The remaining 17 cases are applications for opening offices in Brest (4), 2 cases each for the city of Grodno, the town of Krynki of the Grodno district and the town of Mileychitsy of the Brest district. The rest of the dentists' offices were located in Kobrin, Byten, Molchad, Ruzhany, Kosovo, Slonim district, townships of Mileychitsy and Domachevo, Brest district.

Dental services provided by women dentists were in great demand not only among the Jewish population, but also among Christians. By

\footnotetext{
${ }^{5}$ NHAB in Grodno. F. 103. Inv 1. C. 52. Sh. 1.

${ }^{6}$ NHAB in Grodno. F. 9. Inv. 1. C. 123. 1868 y. 22 sh.
} 
opening their own office, dentists could earn a good income by providing services to the public. So, the Minsk hospital made fillings with cement for 35 coins, porcelain - for 2 rubles. Most of the applicants made fillings from cement, as the cheapest material. So, in 1907 y., 426 cement fillings were delivered, and only 4 porcelain fillings. Tooth extraction under cocaine cost 50 coins, under general anesthesia using chloroform -3 rubles ${ }^{7}$. The financial factor was a serious incentive to open own office.

What was the procedure for opening a dental office in the town of Druskeniki? As a rule, an aspiring dentist first looked for a suitable place in which was possible to equip a dental office. It was necessary to comply with the sanitary and hygienic requirements of the Medical Board for the premises. The building in which the office was located was supposed to be located in a lively and at the same time respectable area. Capital was needed to purchase dental instruments and materials. In the absence of such, there was an opportunity to take a loan from their fellow believers.

In June 1893 y. Tsina Vilkoreyskaya submitted a petition to open a dental office in the Druskeniki resort. In the petition, the applicant states that the office was already equipped, and that the Grodno district doctor must conduct an examination and draw up a report on the examination of the office ${ }^{8}$.Similar applications were made from 1903 to 1907 yy. by Bronya Zuckerman ${ }^{9}$, Sora Vilberg ${ }^{10}$, Dina Linshits ${ }^{11}$, Tsira Rotnitskaya ${ }^{12}$, Rokhlya Mulerio ${ }^{13}$, and Manya Weisbrem ${ }^{14}$. What unites all these women, except for their profession and the desire to open an office exclusively in Druskeniki? The average age of the applicants who wanted to open their own office was 30-32 years. Most of them were trained by freelance dentists. However, there were exceptions in the form of women who received higher dental education.

Thus, in 1908 y., two women, Sarah Livshits ${ }^{15}$ and Rebekah Kveit ${ }^{16}$, simultaneously petitioned to open offices in Druskeniki. Both were gradu-

\footnotetext{
${ }^{7}$ NHAB in Minsk. F. 299. Inv. 3. C. 1278. 1907-1911 yy. 727 sh.

${ }^{8}$ NHAB in Grodno. F. 9. Inv. 1. C. 2039. 1893 y. 6 sh.

9 NHAB in Grodno. F. 9. Inv. 2. C. 737. 1903 y. 12 sh.

${ }^{10}$ NHAB in Grodno. F. 9. Inv. 2. C. 1023.1904 y. 10 sh.

${ }^{11}$ NHAB in Grodno. F. 9. Inv. 2. C. 1026. 1904 y. 16 sh.

${ }^{12}$ NHAB in Grodno. F. 9. Inv. 2. C. 1435.1905 y. 12 sh.

${ }^{13}$ NHAB in Grodno. F. 9. Inv. 2. C. 2151.1907 y. 11 sh.

${ }^{14}$ NHAB in Grodno. F. 9. Inv. 2. C. 2137.1907 y. 29 sh.

${ }^{15}$ NHAB in Grodno. F.9. Inv. 2. C. 2523. 1908 y. 3 sh.

${ }^{16}$ NHAB in Grodno. F. 9. Inv. 2. C. 2527. 1908 y. 6 sh.
} 
ated from Kharkov University. And if there were no claims to Sarah's documents and the applicant immediately received permission to open the office, then Rebekah's documents raised suspicion of authenticity. The medical department sent a request to the Ministry of Public Education and the Chancellery of the Council of the Imperial Kharkiv University to doublecheck the information on her dentist certificate. At the same time, a request was made to the Office of the Grodno Governor about the political reliability of the applicant. All documents turned out to be genuine, the applicant was politically reliable, so there were no obstacles to issuing a permit.

Conclusion. Located on the right bank of the Neman on the border of the Grodno, Kovno and Suvalki provinces, the town of Druskeniki has become an attractive holiday destination for the Jewish population. Combining the unique properties of healing water and environmental friendliness, as well as convenient logistics, the resort was actively developing. Opening of numerous dental offices at the turn of the 20th cent. contributed to the development of Druskeniki as a destination for dental tourism. Jewish women, opening their own offices in Druskeniki, stimulated the development of this tourist destination. At the same time, working in this area, earning her own income, a woman freed herself from patriarchal dependence, destroying gender stereotypes imposed by society. Getting out of the control of the family, running her own business on her own, colliding during her work with representatives of other nationalities, a Jewish woman ended up on the borderlands of cultures. A long process of emancipation and acculturation of the female Jewish population began. The end result of these processes was the formation of a new type of independent woman.

\section{References}

1. Mysh, M. I. (1914). Rukovodstvo k russkim zakonam o evrejah [Guide to Russian Laws to Jews]. SPb, tipografija A. Benke, 640 p. (In Russ.).

2. Shumin, N. (2014). Istoki zubovrachebnogo obrazovanija na territorii Belarusi [The Origins of Dental Education in Belarus]. In: Medicine at the turn of the century: to the 100th anniversary of the First World War. Grodno, p. 464-467. (In Russ.).

3. Sabaleyskaya, O. (2012). Amatary lyachyzza: sanitary, hvaroby i medytsyna u Gabrejskaj Garodni XIX - patch. XX stagoddzia [Lovers of medicine: hygiene, diseases and medicine in Jewish Grodna XIX - begin. XX centuries]. In: Hrodna Palimpsest. 2010. Person, Society, State XV-XX cent. Minsk, Zmitser Kolas, p. 207-230. (In Belaruss.).

4. Berger, N. (1997). Jews and Medicine: Religion, Culture, Science. Philadelphia-Jerusalem: The Jewish Publication Society. 275 p. 
5. Subbotin, A. P. (1888). V chertie evrejskoj osedlosti: otryvki iz ekonomicheskih issledovanij v zapadnoj i jugo-zapadnoj Rossiji letom 1887 g. [Within the Boundaries of Jewish Settlement: Excerpts from Economic Research in Western and Southwestern Russia in the Summer of $1887 \mathrm{y}$.] $\mathrm{SPb}$. tipografija «Economiczeskij jurnal». Issue. 1.148 p. (In Russ.).

6. Z tygodnia (1881). [From a week]. In: Izraelita. No. 6 (30 January). P. 46. (In Pol.).

7. Pogadanki (1879). [Chats]. In: Izraelita. No. 26 (22 June - 4 July). P. 216. (In Pol.).

Received: 16.11 .2020$.

About authors: Yuliya Yarmak - Magistr of Political Science, Senior Lecturer at the Department of Tourism and Cultural Heritage, Faculty of History, Communication and Tourism, Yanka Kupala State University of Grodno; e-mail: Ermak_JG@grsu.by

DOI: $10.33581 / 2311-9470-2020-8-147-159$

\section{ИСТОРИЧЕСКАЯ РЕТРОСПЕКТИВА: ЕВРЕЙСКИЕ ЖЕНЩИНЫ БЕЛАРУСИ В РАЗВИТИИ СТОМАТОЛОГИЧЕСКОГО ТУРИЗМА (ВТОРАЯ ПОЛОВИНА 19 - НАЧАЛО 20 ВВ.)} Ю.Г. ЕРMAK

Гродненский государственный университет имени Янки Купальг Гродно, Республика Беларусь

В статье на основе архивных документов будет рассмотрено такое направление туристической индустрии, как медицинский туризм. В Беларуси стоматологи были пионерами в этой области, но история этой отрасли намного старше, чем можно было бы подумать. В конце 19 - начале 20 вв. черта оседлости евреев проходила по территории Беларуси. Белорусские губернии, в которых сосредоточена значительная часть еврейского населения в тот период, вступили в период кардинальных изменений. Процесс модернизации привел к появлению женщин в общественных сферах. Со второй половины 19 в., после разработки нормативной базы, появляется возможность получить специальность стоматолога. Архивные документы из Национального исторического архива Беларуси (НИАБ) в Гродно и Минске показывают, что стоматологическая промышленность была очень привлекательна для еврейских женщин. Друскеники были особым местом для еврейского населения. Женские еврейские стоматологические кабинеты пользовались большим спросом не только среди еврейского населения, но и среди христиан. Эта деятельность дала женщинам 
возможность иметь собственный доход, а значит, освободила их от патриархальной зависимости, разрушив навязанные обществом гендерные стереотипы. Начался процесс эмансипации женского еврейского населения. Конечным результатом этих процессов стало формирование на рубеже $19-20$ вв. независимой женщины.

Ключевые слова: еврейские женщины; черта еврейской оседлости; туризм; зубной врач; Друскеники; гендерные стереотипы.

Образец цитирования: Yarmak, Y. (2020) Historical retrospective: jewish women of Belarus in the development of dental tourism (second half of the $19^{\text {th }}$ - early 20th cent.) // Актуальные проблемы международных отношений и глобального развития: сб. науч. ст. Минск, 2020. Вып. 8. С. 147-159. https://doi.org/10.33581/2311-9470-2020-8-147-159

Дата поступления статьи: 23.11.2020.

Автор: Ермак Юлия Геннадьевна - магистр политических наук, старший преподаватель кафедры туризма и культурного наследия факультета истории, коммуникации и туризма. УО «Гродненский государственный университет имени Янки Купалы»; e-mail: Ermak_JG@grsu.by 